\title{
ESSENCE OF UNITED NATIONS OFFICE OF COUNTER TERRORISM AT THE TIME OF GLOBAL PANDEMICS
}

\author{
Sarteep Mawlood ${ }^{1}$ \\ ${ }^{I}$ Postgraduate student, «KROK»University, Kyiv, Ukraine, e-mail: sarteep30@gmail.com, ORCID: \\ https://orcid.org/0000-0002-0663-208X
}

Abstract. Although the world lives in an abnormal situation due to the current pandemic COVID-19 which has spread in almost all states and countries, the threat of terrorism are still standing on the ground, but also some of their violent activities, killing, spreading fear have increased in some places. The states are preoccupation with their subjects, people as well as United Nations and other international organizations attempt continuously to eliminate the pandemic permanently, but still needs time, so the terrorist groups exploited it to make damages as much as can, so here the essence of the office appears as it is the professional to act with such as cases but still needs help of other states, agencies and other national, international foundations, which the situation cannot stand anymore if the states do not put their interests aside and work for whole international community due to the high level of risk of terrorism.

Keywords: state members of General Assembly, Counter Terrorism Office, ideology, religion, health pandemic, coordination, public interest, international peace, agencies, awareness, exploitation, threat, human rights.

Jel Classification: K14, K30, K40

Formulas: 0; fig.: 1; tabl.: 0; bibl.: 8

Introduction. Although the counter terrorism office has been founded to fight against terrorism acts as well as to improve the ability of the United Nations, but still face a lot of challenges from time to time and from place to another, the recent challenges of the office is COVID-19 that due to this pandemic, extremist groups could reorganize their tactics, ways of attacking, hiding inside crowds, having technologies, and improve their abilities. The office of counter terrorism should have alternative ways, tactics to deal with such as cases that can face terrorism, meanwhile does not violate human rights.

Literature review. During the article various cases analyzed that counter terrorism will be just a normal office and cannot do its duties without fully coordination of states other agencies, and faces more challenges when there is such natural or no natural disasters, pandemic which leads international community to be ready for it and have more chance to deal with the situations. According to "Fink N. C., 2012, in his book under name, meeting the challenge, a guide to united nations counterterrorism activities" in the last decades the work of the United Nations against terrorism has been expanded through initiatives of the General Assembly and the security council and it means that there is a good relationship among countries in United Nations organ to defeat terrorism and destroy it, because the threat posed by terrorism today is therefore complex, globalized, diffused, and sometimes connected to a number of other transnational threats. So the threat of terrorism is increasing day after day because of developing technologies and terrorists wish to have it and use it to have more damages, besides the relationship and coordination among states is not on that high level, almost all states determine radical groups on how the groups close to their interest, not depend on the universal standard or radicalism. While C.S.R 
Murthy, sees in his book (The U.N. Counter-Terrorism Committee: An Institutional Analysis, 2007) It is indisputable that terrorism is a pervasive and pernicious threat to global security and order. To make the combat against terrorism universal in scale, the United Nations has become a natural forum in view of its unique value and experience in addressing a wide variety of complex problems of global character. As a kingpin among several UN mechanisms addressing different aspects of the menace, the Counter-Terrorism Committee (CTC) of the Security Council signifies robust institutionalization of the international community's sensitivity to the imperative of effective collective action to deter terrorism acts.

Aims. The aim for the article is to find out what are the challenges before the counter terrorism office, how to deal with cases, how be ready and adapt itself for unexpected situations such as we are in the current situation, how to make the office performs better in future.

Methods. Methodology of the article depends on several analyzes of other studies related to the title, various information, studies, views have been gathered to reach the better solution as well as pave the ways for others to make further ideas, synthesize with other structures, besides analyze other concerning articles, theses and ideas which already had on the topic, through all of these critical information we tried to have conclusion which can be solutions for some countries, places or at least will be basic ground for other researches because the method based on important structures of research as well as performed to gather as much information as relevant from previous studies which can provide readers enough statistics and gives key points to prove their theses, views, ideas, optional solutions which contributes achievement of the goal and can be source for other researchers.

Results. As an instrument of promoting international cooperation, the value of the United Nations can be potentially unique. Notwithstanding the fact that terrorism constitutes a serious threat to the core values of the UN, critics write that the response of the world organization to terrorism has been "tentative, halting, and even ambivalent". Two explanatory factors are cited. First, doubts about the capacity of the United Nations to rise up to the challenge alongside - ironically enough - a realization that no viable multilateral alternative exists for dealing with terrorism. Secondly, lack of common agreement on the legality and legitimacy of counterterrorist measures carried out unilaterally or in groups without the backing of the UN bodies.

The attacks against the United States in September 2001 pushed the United Nations to begin working on a suitable and agreeable strategy on counterterrorism. As a first step, the Secretary General had set up in October 2001 a policy working group which in its report cautioned against 'offering, or being perceived to be offering, a blanket endorsement of the measures taken in the name of counterterrorism' and that UN efforts to 'reduce terrorism must not be at the expense of its core responsibilities' like development. The Group very wisely acknowledged the operational inability of the UN to pre-empt specific terrorist strikes or to develop dedicated intelligence capacities and highlighted the potential of a three-pronged strategy centered round the areas of the world body's comparative advantage. 
Accordingly, the UN could work to dissuade the disaffected groups from pursuing terrorism for redress of grievance if any; deny groups and individuals the means to carry out acts of terrorism; and sustain broad-based international cooperation in the struggle against terrorism [1].

The United Nations Office of Counterterrorism (UNOCT) was established on 15 June 2017 through the adoption of UN General Assembly Resolution 71/291. The creation of the Office is considered as the first major institutional reform undertaken by the UN Secretary-General following his report (A/71/858) on the Capability of the United Nations to Assist Member States in implementing the United Nations Global Counter-Terrorism Strategy. Some of the main functions of the office are:

1. Enhance coordination and coherence across the Global Counter-Terrorism Coordination Compact entities to ensure the balanced implementation of the four pillars of the UN Global Counter-Terrorism Strategy

2. Strengthen the delivery of United Nations counter-terrorism capacity-building assistance to Member States

3. Ensure that due priority is given to counterterrorism across the United Nations system and that the important work on preventing violent extremism is firmly rooted in the Strategy.

On 23 February 2018, the Secretary-General signed the new UN Global Counter-Terrorism Coordination Compact, which replaced the Counter-Terrorism Implementation Task Force coordination arrangement. The Compact aims to strengthen a common action approach to coordination and coherence in the counterterrorism and prevention of violent extremism (CPVE) work of the United Nations system, and to strengthen support to Member States, at their request, in the implementation of the UN Global Counter-Terrorism Strategy and other relevant United Nations resolutions and mandates. UNOCT works in close collaboration with the Security Council subsidiary bodies mandated to enhance the capacity of Member States to prevent and respond to terrorist acts [2].

Despite these comparative advantages, it is broadly acknowledged among policymakers at the $\mathrm{UN}$ and in several member-state missions that the $\mathrm{UN}$ is less suited to taking on the more militarized tasks associated with fighting terrorism. As the Policy Working Group acknowledged, the UN is not "well placed to play an active operational role in efforts to suppress terrorist groups, pre-empt specific terrorist strikes, or to develop dedicated intelligence-gathering capacities. Without a standing army or any independent military capacity, the UN cannot engage in any kinetic counterterrorism operations, nor does it have sufficient resources at this time to devote to the development of a strong independent analytical capacity to assess the threat and formulate the necessary response. Furthermore, the UN is an unlikely vehicle for sharing sensitive national security information given the differences among the membership regarding the definition of terrorism and the inability of the world body to place any guaranteed safeguards on classified information. Consequently, the willingness of states to utilize multilateral tools in addressing terrorism has been variable, with many preferring to channel counterterrorism resources through bilateral arrangements or regional/sub regional organizations. 
Nonetheless, for many states, the UN remains a trusted partner, especially when overt bilateral engagement on counterterrorism is fraught with political sensitivities.

Also in regions where political tensions inhibit counterterrorism cooperation at the political level, the UN is well placed to be a neutral convener for practitioners and key stakeholders to develop cooperative professional networks and to exchange best practices. Differences among the UN membership on how to address terrorism reflected the views of two main blocs. Primarily developed states in the Global North advocated a zero-tolerance approach while primarily developing countries in the Global South expressed concerns about the diversion of development and other resources towards what they perceived to be a Western/Northern security agenda that had little relevance to their own priorities.

Moreover, many of these states owed their independence to successful anticolonial movements and reflected this history in their reluctance to label those they perceived to be freedom fighters as terrorists [3]. The international community is facing a human crisis unlike any other since the founding of the United Nations. COVID-19 continues to devastate lives and livelihoods, hitting the most vulnerable and marginalized the hardest. It has unleashed a tsunami of misinformation, hate speech, xenophobia and conspiracy theories. It also has the potential to act as a catalyst in the spread of terrorism and violent extremism by exacerbating grievances and inequalities, undermining social cohesion and fueling local conflicts. Terrorists are already exploiting the significant disruption and economic hardships caused by COVID-19 to spread fear, hate and division and radicalize and recruit new followers.

The pandemic has also highlighted vulnerabilities to new and emerging forms of terrorism, such as cyber-attacks against critical national infrastructure and the weaponization of deadly diseases. The successful delivery of the Virtual Counterterrorism was a major achievement as the United Nations' first global conversation on the evolving terrorism threat and counterterrorism responses in a pandemic environment.

It improved our collective understanding of the impact of COVID-19 on the counter-terrorism priorities of Member States. It underscored the importance of international cooperation, respect for human rights and the rule of law, and a wholeof-society approach to effectively prevent and counter terrorism. It also raised awareness of the transformation in the way that the United Nations provides capacity building support to Member States and regional organizations, in line with the all-ofUN approach embodied by the United Nations Global Counter-Terrorism Coordination Compact [4].

The Security Council renewed its determination to further strengthen the unified and coordinated international response against those heinous acts. Acting under a temporary silence procedure induced by the COVID-19 pandemic, Tunisia, Council President for January, issued a presidential statement (document S/PRST/2021/1), in which the 15-member organ reaffirmed that terrorism in all forms and manifestations continues to constitute one of the most serious threats to international peace and security. 


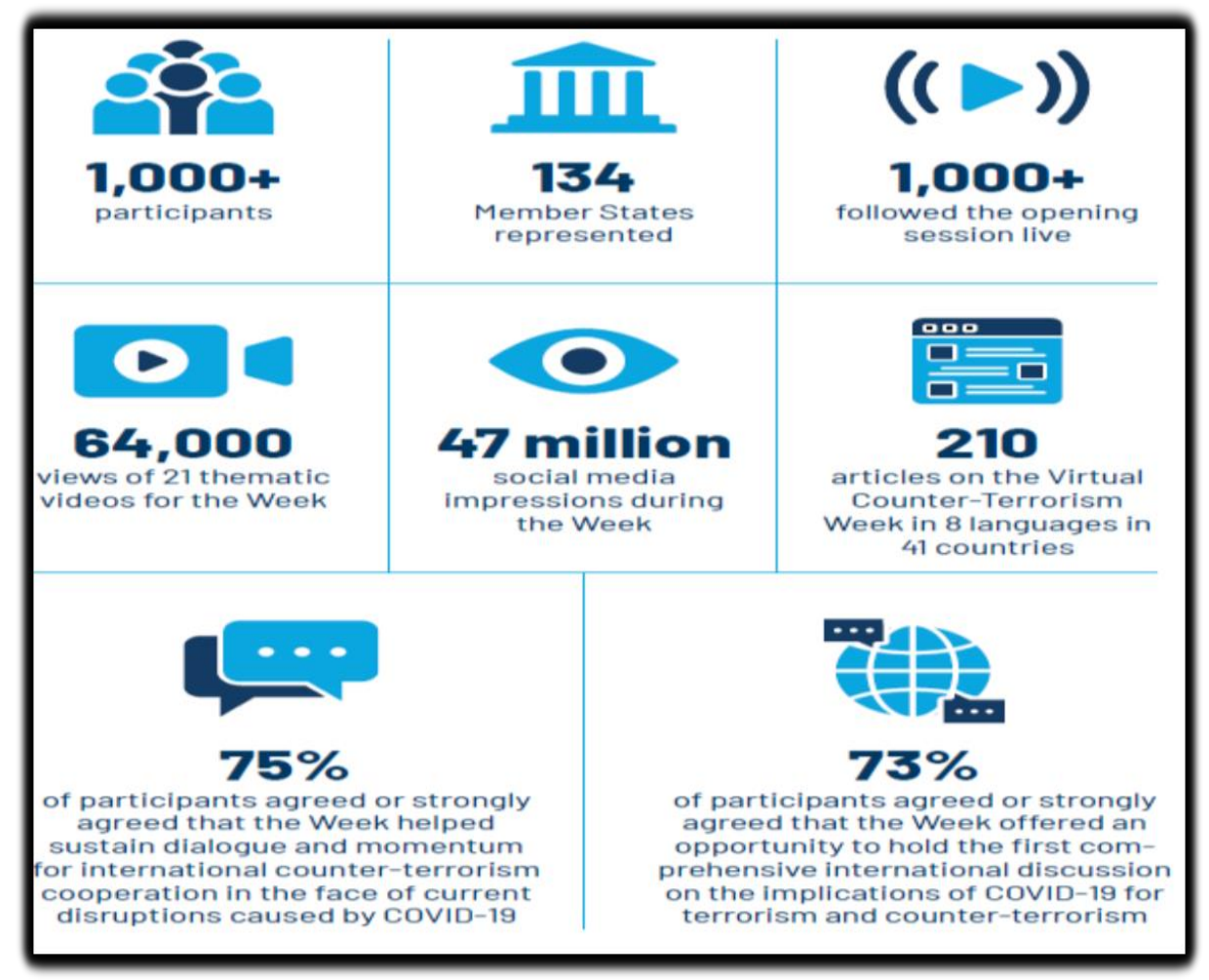

\section{Figure 1. Showcasing the work of UNCCT: the 'Virtual Expo' raised the visibility of UNCCT's capacity-building activities, programs and confirmed its reputation as a global center of excellence serving Member States and the international community $\mathbf{2 0 2 0}$}

Sourse: [4]

Reiterating the obligations of Member States to prevent and suppress the financing of terrorism, the Council highlighted the need to enhance cooperation among its various relevant committees and develop effective partnerships among the United Nations, regional and sub regional organizations in countering terrorism. Underscoring the importance of strong coordination and cooperation between the Counter-Terrorism Committee and its Executive Directorate (CTED) and the United Nations Office of Counter-Terrorism, the Council further underlined those entities' invaluable aid to Member States through technical assistance and identifying capacity gaps to implement resolution 1373 (2001) and relevant subsequent texts "In the face of these threats, this Council has provided critical impetus and guidance for Member States to demonstrate unity of purpose and action, stepping up national efforts and international cooperation.

This has led to important successes, helping Member States to bring terrorists to justice and to disrupt more attacks. Even the terrorists in Iraq and Syria were defeated, although it remains a threat in the region. Terrorists have sought to exploit disruptions arising from COVID-19, he warned, attempting to benefit from the setbacks to the development and human rights agendas, riding on the wave tops of polarization and hate speech amplified by the pandemic. The threat has become even more difficult to prevent, with low-cost, low-tech attacks against soft targets by so- 
called lone wolves [5]. Partnerships involving governments, civil society, and CSOs on their own also make important contributions to shorter-term preventive counterterrorism and related efforts.

For example, interaction between governments and CSOs on the issue of small arms and light weapons (an issue that is explicitly mentioned in the Strategy) has developed into an effective partnership in the past time. Similar efforts have also flourished between government and nongovernment experts seeking to address the threat of illicit transfers of biological, chemical, and nuclear materials to potential terrorists. CSOs are also making conscious and significant contributions to measures to prevent terrorism in the implementation and monitoring of security sector reform activities, which are linked to a state's ability to carry out effective law enforcement and other security-related counterterrorism measures. Some CSOs, especially research organizations, also foster closer, cooperative initiatives involving states and other stakeholders to improve and raise awareness of threats and encourage collective action to address vulnerabilities.

The UK Department for International Development, for example, has noted that: Improving civic awareness of security issues is a starting point for improving relations between the security forces and the public, creating a national consensus on a reform programmer, and building political coalitions to sustain the process. Civil society can also play more specific roles by facilitating dialogue, monitoring the activities of the security forces, and expressing views on security policy as well as providing policy advice. This may be particularly useful where state capacity is weak: the role of legislatures or other government departments in analyzing security issues, for instance, can be greatly enhanced by assistance from specialist external campaigning groups or think tanks providing research and analytical support. In addition to long-term efforts to address causes conducive to the spread of terrorism, the Strategy in its second pillar reaffirms states' existing UN mandated counterterrorism obligations to implement security-focused measures to address the terrorist threat, including judicial, police, and other forms of law enforcement cooperation, and comprehensive counterterrorism legislation [6].

The new Counter-Terrorism Office marked a milestone in efforts to improve United Nations efficiency in fighting terrorism, delegates in the General Assembly, calling on its freshly appointed head to strengthen coordination among the 38 agencies, funds and programs, and affiliated organizations to end the scourge. With that in mind, the representative of the United States said the Office must prioritize the Secretary-General's action plan to combat terrorism by promoting preventive measures that addressed the drivers of extremism. It should also engage local civil society, especially young people and women, and promote respect for human rights. More broadly, speakers from Nicaragua, Maldives, United Arab Emirates, Qatar, Bangladesh and the Philippines were among those warning against linking terrorism to any culture, religion, ethnicity or nationality, with Saudi Arabia's delegate stressing that fighting extremist ideology must remain a priority [7].

Discussion. According to the mandate of establishment of the United Nations office of counter terrorism there are good points which make real coordination among 
states and other legal entities to have coordination, collaboration and strengthen support to the member states, but on the ground is something else, not just there is a good coordination among members but some states charges other states for helping violent groups, terrorists and implement other agenda which can create dangerous on each other.

The UN had confessed that the response of global community against the terrorism is not in that level, it was temporary which cannot solve the root issues, was not on progress all the time as well as there was contradictions among states on how to face the challenge, so it made the process went slowly. Meanwhile the community was and still in dangerous because of the real threaten of the terrorism acts, so they found out that there is no alternate plan for the multilateral dealing with the violent acts which are used by the radical groups, in another hand the terrorism can attack states more easily if the community does not confront the high level of threat. Besides the United Nations has not military power to fight with terrorism which it is a big defect on the biggest international organization, makes UN inappropriate foundation as it is responsible to keep international peace and security not just that but has not ability to have enough intelligent information about terrorism acts which prevent it before performing, as long as UN stays in that position then cannot play an active operation to suppress terrorism, in another side states want to strengthen lateral capacity in all fields of technology, intelligent, military, weapons, and other spaces.

After appearance of corona virus COVID-19 the international community faces another challenge which hits the most vulnerable and poor people that took life from more than million people in all around the world in different ages, ethnics, colors, religious, and it gives more opportunity to the terrorists to reorganize themselves again in some places, which makes international community to cooperate better and hit the terrorist with one united hand, but meanwhile human rights, sovereignty of states should be respected and does not exceed on other rights by the name of fighting terrorism.

According to the latest resolution of the majority of members of Security Council that the terrorism is still the one of the most challenges risk on humanity in general and on international peace and security which means the members of the states should more effort to prevent the heinous acts wherever they are, show more active acts, make better coordination to those offices which are related to the counter terrorism, almost all were agreed that terrorists exploited chance to attack civils, governmental foundations, and other national and international entities during the corona virus.

Besides Security Council made double check to patch the hole with deliberation intelligence and useful information among state members which helps them to find where the weak points are and what the strong points are as well. Fighting terrorism lies with everyone, state, entity and our all responsibility not on a specific country or person, but on states, governments, regional entities, international entities, civil societies, or any other foundations and centers who have any kind of positive effect, have contribution to solve the issues or at least lessen violence inside and outside the country, which can help the international community to control the situation, 
understand where and what is needed, on this base national and international organizations should have coordination and performing more active role to raise awareness among people, make them have enough information that violence is against human being despite of having different ideas, ideology.

It is clear that the counter terrorism office has been founded to strengthen United Nations ability to protect international community from terrorist attacks wherever it be and it is emphasized several times by General Assembly of United Nations, and that is the priority of the counter terrorism office, but while doing any kind of activity by the office the safety of human being, their rights should be protected and not be done hierarchy, as well as most states are agree that terrorism has no relationship with religion, culture or races as some think terrorists belong to specific religion in particular with Islam, but it is totally wrong, none of religious allows extremist ideology nor permits to act violent against others.

Conclusion. United Nation office of counter terrorism is created for specific purpose and it is to fight terrorism as it is named, and it is impossible to gain the goal without perfect relationship among states, the mandate of the office becomes a blue print if the states which already signed the mandate do not keep and respect their signing, meanwhile it is international community in general and security council particularly to keep the world peaceful, out of violent, prevent terrorism act wherever the acts are. Throughout the history and study of the cases reached to the point that should be global agreement on crucial matters which are community consideration, it is a very simple equation that two is better and stronger than one, three more than two etc.

States should leave their private and personal interests for whole community, as today on me tomorrow on you, so no one is excepted from terrorism and let us unite for facing the serious threat, otherwise the United Nation will face the same dissolution as happened to the league of Nation during the second world war due to incapacity to stop the war among states and because there were various directions of views as well as personal interests. It is still not too late if the global community takes necessary steps, it is the United Nations responsibility to defend its principles and volumes, let them to clear things up and the main thing is point out the which states are not with, which are with, they should be more direct and straight, stop beating around the bush because poor people are the main targets of the terrorism.

Neither United Nations nor the office of counter terrorism is able to fight terrorism acts if the states members do not fully associate with the United Nations committees and offices which are regarding confrontation terrorism violent, membership of states is not just blue print and by name but it is by practical things which means membership of states in United Nations almost means nothing if do not give those technologies which are necessary for United Nations, instead of empowering international organization such as Un, states empowered reginal and continental organizations such as NATO, it is good that states, regions, continents have bilateral, multilateral relationship and coordination, but better to have those relationship in United Nations as well and not characterized only by ethnic, nations, races. The planet of earth in general and the international community since been 
created was not and still not far from pandemics, wars, plague, disasters which some were artificial by people who had interested in events, and some were natural disasters which human being had nothing relating with, so just like the COVID-19 no one is far from the pandemics is also true to the terrorism and no one will be excepted from their attacks, that's why the essence of the counter terrorism office is so important and more important is to follow up the updates during the pandemic, the most powerful weapon we can use to change the world and make it better is to be united and fight the terrorism together, the big challenge is every state during the virus considers its issues and affairs through its territory and became far from other international issues which at the end there is no border for the pandemic as it was appeared in a country at first and now no place is safe.

Through the history of United Nations tens or hundreds of resolutions have been taken in regards with the terrorisms in particular and heinous acts in general for preventing terrorism acts, crush the financial root, lessen violence against community, meanwhile protect and keep the international peace and security but in fact violence acts including terrorism are increased, the most recent solution which issued by the majority members of Security Council was in January2021 during the corona virus especially for those issues which are related to the terrorist acts, international peace and security, but on the ground the other things have seen which are far from the issued solution they have decided, it means issuing resolutions for the state members are not enough if not fulfilled on the ground, the lesson is in its implementing not in issuing or ratifying, as they say actions speak louder than words, so words become just blue print if we all do not go for acting in active way.

Terrorism, violence, and fear spread in all around the world, it might happen in everywhere, so we as states, individual person, people, governments, civil societies, entities and other stakeholders to take the dangerous seriously and try to raise awareness among society, no one may not be ignored because everything has its effect on the society, but the effect should be in positive way not negative, as from time to time and place to another we see violation of human rights, obstacles of movements, freedom of expressions all of those things make wider field to the terrorists to do their acts and to exploit people, unfortunately nowadays even in developed countries discrimination among people have seen, but often happens in those countries with dictator system or one political party which others are not allowed to have their political party, speak and study in mother tongue, other things.

Every single gap in society has negative effect and spread hate, fear which led to the violence at the end terrorism acts and groups, actually real humanitarian organizations had a good role in this field, many people got benefit from their information, courses, workshops, which explains how lovely the friendship relationship among societies, nations, cohesion is something that we need to get used with it as there are various races, nations, religions, cultures live in a state. Even if the counter terrorism office is available but cannot perform its duties well if other states, agencies, local governments do not cooperate with the office, in another hand the office should publish fliers of awareness regarding moderate ideologies, give more explanation for people who have no enough information about different religious as 
some think violent belongs to specific religion due to bad imagination or publish wrong information on religious especially on Islam, but in fact it is against any kind of violent acts, as it is mentioned in holy Quran ( There is no compulsion in religious), how it is possible to cat violently against people but it is tolerance and rejection religion.

\section{References:}

1. Murthy C.S.R (2007) The U.N. Counter-Terrorism Committee: An Institutional Analysis retrieved from: https://library.fes.de/pdf-files/iez/04876.pdf

2. The official site of United Nations, office of counter terrorism, counter terrorism mandate, retrieved from: https://www.un.org/counterterrorism/about

3. Fink N. C. (2012) meeting the challenge, a guide to united nations counterterrorism activities retrieved from: https://www.ipinst.org/wp-content/uploads/publications/ebook guide to un_counterterrorism.pdf

4. Voronkov V (2020) Virtual counter terrorism week, visibility report, retrieved from: https://www.un.org/counterterrorism/sites/www.un.org.counterterrorism/files/20201104_virtual_ct_wk_visbility_report .pdf

5. The official site of United Nations, SC/14408 (2021) Security Council, Meetings Coverage and Press Releases, 20 Years after Adopting Landmark Anti-Terrorism Resolution, Security Council Resolves to Strengthen International Response against Heinous Acts, in Presidential Statement retrieved from: https://www.un.org/press/en/2021/sc14408.doc.htm

6. Rosand E., Millar A., Ipe J (2008) Center on Global Counterterrorism Cooperation, Civil Society and the UN Global Counter-Terrorism Strategy: Opportunities and Challenges, retrieved from: https://www.globalcenter.org/wpcontent/uploads/2008/09/civil_society.pdf

7. The official site of UN OCHA service (2017) Speakers in General Assembly Urge Head of New Counter-Terrorism Office to Strengthention United Nations System Coordination towards Preventing, Ending Menace, retrieved from: https://reliefweb.int/report/world/speakers-general-assembly-urge-head-new-counter-terrorism-office-strengthen-united 8. Mawlood, S. (2020). Global view of the main reasons terrorism emergence. Public Administration and Law Review, (3), 95-108. https://doi.org/10.36690/2674-5216-2020-3-95.

Received: November 25, 2021

Approved: December 24, 2021 